\title{
Factors Related To The Standard Of Care And Installation Of A Dower Cateter In A Hospital
}

\author{
Mohamad Judha', Ayu Silviana Rulis ${ }^{2}$ \\ 1, 2 Staff Nurse and Lecturer in Universitas Respati Yogyakarta \\ Email : judha.fikesunriyo@gmail.com
}

\begin{abstract}
Urethral catheter placement is a form of nursing care performed by nurses, a standard for catheter placement is required. Urinary tract infections often occur around $40 \%$ of all hospital infections each year. In addition, from some researchers, $80 \%$ of urinary tract infections occur due to the use of catheterization instruments, because almost 10\% of all hospitalized patients, at Bantul Hospital in 2017 There are $21 \%$ of patients are infected with the urinary tract. Nurse compliance uses standards based on various factors. Research Objectives :To determine the factors associated with the participation of nurses in the implementation of the standard installation of urethral catheters Research Methods: Descriptive analytic research by discussing the cross-sectional study. The sample used was total sampling with a sample of 43 nurses according to inclusion criteria. Data collection tools using questionnaires and observation sheets. Chi-Square data analysis with $\alpha<0.05$. Results: The gender of female respondents was $76.7 \%$. Age of respondents received $18-40$ years $76.7 \%$. The level of knowledge of respondents in the good category is $65.1 \%$. The attitude of respondents in the positive category was $83.7 \%$. The working period of respondents $<5$ years $51.2 \%$. There is a significant relationship to age with the implementation of the standard implementation of urethral catheters, $(\mathrm{P}=0.003$ with an OR value of 2.54). There is a significant relationship between knowledge and the implementation of standard urethral catheter placement $(\mathrm{P}=0,000$ with an $\mathrm{OR}$ value of 19.50). There is a significant relationship between attitude with the agreement on the implementation of the standard urethral catheter installation $(\mathrm{P}=0.007$ with an $\mathrm{OR}$ value of 0.361). There is a significant relationship between a work period and the implementation of the standard implementation of urethral catheters $(P=0,000$ with an OR value of 20.40).
\end{abstract}

Conclusion: There is a significant relationship between age, knowledge, attitudes, and years of service to the approval of nurses in the implementation of the standard installation of urethral catheters in care in Bantul Hospitall

Keywords : Working period of a nurse, and catheter installation standards 


\section{INTRODUCTION}

Urinary tract infections are nasocomial infections that often occur around $40 \%$ of all hospital infections each year (Burke and Zavasky, 1999). Additionally, from some researchers $80 \%$ of nosocomial UTI (urinary tract infections) occur after the use of instruments, especially catheterization (Asher, Oliver and Fry, 1986), because almost $10 \%$ of all hospitalized patients use a catheter, prevention of UTI infections is a major factor in reducing nasocomial infections, (Tietjen, 2005).

In developing countries the occurrence of nosocomial infections is high due to lack of supervision, lack of compliance with standards, poor prevention practices, inappropriate use of limited resources and overcrowded hospitals by patients (Sumaryono, 2005). Survey data conducted by AMRIN (Anti Microbal Resistance In Indonesia) research group, in Dr. Kariadi Semarang in 2002, the highest incidence was $11 \%$ Sugiono, (1999) in Kasmad, (2007).

Installation actions that are not good or not in accordance with the standards must be removed by providing quality services and good care. Based on the results of research in October 2016 to March 2017 conducted in DKI Jakarta, North Sumatra, North Sulawesi and East Kalimantan in
20017 by WHO and the Directorate of Nursing at the Ministry of Health, one of the results was that optimal standards for the implementation of tasks had not been developed yet.

The results of previous studies that showed that catheter placement and dressing were not good or were not in accordance with fixed procedures, among others, there was still a long urethral catheter installation for more than 15 days Riyantinah (1999). In the research Ribek (2000) showed the compliance of nurses in the implementation of standards, one of which is the standard installation of urethral catheters not yet implemented $100 \%$ of nurses.

Catheterization is the act of inserting a rubber or plastic tube through the urethra and entering the bladder (Alimul, 2004). Catheterization must be carried out according to standards, to prevent urinary tract infections (UTIs). UTIs that occur because the catheterization is not good or not according to the standard, there are several factors that affect compliance. include gender, length of work, age, attitude and knowledge.

Based on preliminary studies conducted by researchers, the results of the number of patients with catheters on the ward totaled 64, with 22 nurses reporting Nasocomial Infection in Bantul Hospital, the incidence of infection, especially in 
cases of urinary tract infections in 2016, there were $21 \%$ of people experiencing UTI, the reporting section states there are still many who have not reported the incidence of infection from each ward in 2016, so that the data has not yet fully received a report from each ward. The results of a preliminary study at the time of observation on the ward found gaps in urethral catheter placement, among others: at the stage of orientation was not perfectly done, did not replace sterile gloves, did not put sterile duk and did not use perlak, at the evaluation stage was not perfectly done.

Based on this problem, this is the researcher's starting point why it is necessary to examine factors related to nurses' compliance in the implementation of the standard installation of urethral catheters in inpatients in Bantul hospital.

The general objective of the study was to determine the factors associated with nurse compliance in implementing standard urethral catheter installation in Bantul Hospital, the specific purpose of this study was to determine the distribution of gender, age, knowledge, attitude and length of service to nurse compliance in implementing standard installation urethral catheter at Bantul Hospital

\section{RESEARCH METHODS}

This research is a descriptive analytic study with cross sectional approach, with quantitative research type. The research was conducted data collection conducted December 2016 to March 2017, in the inpatient ward. Sampling technique using a total sample technique of all nurses implementing the ward is 43 samples, with inclusion criteria and which have been set by researchers, namely:

1) Implementing nurses in the inpatient ward

2) Willing to be a respondent is proven by signing an imformed consent

3) Nurse graduates from D III.

This research variable uses a nominal measurement scale. The variables in this study consisted of:

1. Independent variables include (age, sex, knowledge, attitude and years of service), age is categorized as Young if the age is 18-40 and Old if age is 41-57, gender is categorized as female and male, knowledge is categorized as good and unfavorable, attitudes are categorized as positive and negative, and years of service are categorized as long working periods if $\geq 5$ years and new tenure if $<5$ years.

2. The dependent variable is nurses' compliance in implementing catheter installation standards. In this study the dependent variable is nurse compliance categorized as compliant if $\geq 75 \%$ 
of the total number of standard implementation of the installation of the Urethral Catheter is performed. Not compliant if $<75 \%$ of the total number of standard implementation of the installation of the Urethral Catheter.

Data collected in this study are primary data, using questionnaires in the form of questionnaires and observations. Data collection by questionnaire containing questions and data collection by observation technique check list. Then pro ceed with univariate and bivariate analysis using the chi square formula.

\section{Result}

\section{Deskripsi Data Penelitian}
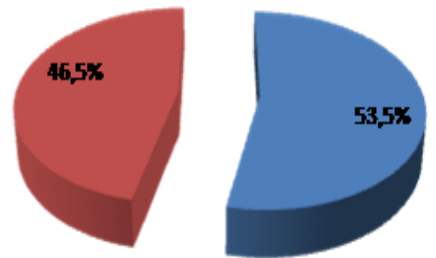

I obey

- disobey

Diagram 1. Nurse compliance in implementing standard urethral catheter installation in Bantul Hospital inpatient

From the diagram above, it is known that most nurses adhere to catheter installation standards as many as 23 people (53.5\%), while nurses who do not comply implement catheter installation standards as many as 20 people (46.5\%).
Table 1. Distribution of Respondent Frequencies by Age, Gender, Working Period, Knowledge and Attitude in the Inpatient Room of Panembahan Senopati Hospital, Bantul.

\begin{tabular}{lllll}
\hline $\mathrm{n}$ & Variabel & $\begin{array}{l}\text { kategor } \\
\mathrm{o}\end{array}$ & $\begin{array}{l}\text { frekuens } \\
\mathrm{i}\end{array}$ & $\begin{array}{l}\text { persentas } \\
\mathrm{i}\end{array}$ \\
\hline 1 & Age & Old & 10 & $23,3 \%$ \\
& & Young & 33 & $76,7 \%$ \\
& Total & & 43 & $100 \%$ \\
\hline 2 & Sex & Wome & 33 & $76,7 \%$ \\
& & $\mathrm{n}$ & 10 & $23,3 \%$ \\
& Total & Men & 43 & $100 \%$ \\
& & & & \\
\hline 3 & Experianc & Old & 21 & $48,8 \%$ \\
& e inwork & New & 22 & $51,2 \%$ \\
& & & 43 & $100 \%$ \\
& Total & & & \\
\hline 4 & Knowledg & good & 28 & $65,1 \%$ \\
& e & Poorly & 15 & $34,9 \%$ \\
& & & 43 & $100 \%$ \\
& Total & & & \\
\hline 5 & Sikap & Positif & 36 & $83,7 \%$ \\
& & Negatif & 7 & $16,3 \%$ \\
& Total & & 43 & $100 \%$
\end{tabular}

Primer Data 2017

\section{a. Age}

Age data is categorized into young and old. Frequency distribution of categorization of respondent's age data can be seen in the table. Based on the analysis results it is known that most respondents in the old category were 10 people (76.7\%), while respondents in the young category were 33 people $(23.3 \%)$.

\section{b. Gender}

The sex of the respondents consisted of men and women. The frequency distribution of 
respondents' gender data can be seen in the following table. Based on the table above, it is known that the majority of respondents were female as many as 33 people $(76.7 \%)$, while those who were male were 10 people $(23.3 \%)$.

\section{c. Years of service}

The working period is grouped into $<5$ years (new) and $>5$ years (old). The results of data analysis of the respondent's tenure are as follows. Based on the results of the analysis, it is known that most of the respondents work only as many as 22 people (51.2\%), while the rest have worked long time as many as 21 people (48.8\%).

\section{d. Knowledge}

Knowledge level data is categorized into good and bad knowledge. The results of the analysis of respondents' knowledge level can be seen in table 4.1. It is known that most respondents have good knowledge of 28 people (65.1\%). Respondents who have poor knowledge are 15 people (34.9\%).

\section{e. Attitude}

Attitudes are categorized into positive and negative attitudes. The results of descriptive analysis of attitude data can be seen in table 4.1. The results of the analysis revealed that most respondents had a positive attitude of 36 people (83.7\%). A total of 7 people $(16.3 \%)$ have a negative attitude.

\section{Bivariate Analysis}

Table 2. Cross Tabulation of Nurse Compliance Factors with Compliance with the Implementation of Catheter Installation Standards in Bantul Hospital Inpatient

\begin{tabular}{|c|c|c|c|c|c|c|c|c|c|}
\hline \multicolumn{2}{|c|}{ variabel } & \multicolumn{3}{|c|}{ Kepatuahan } & \multirow{3}{*}{$\begin{array}{l}\mathbf{P} \\
\begin{array}{l}\text { Valu } \\
\mathrm{e}\end{array} \\
\%\end{array}$} & \multirow{3}{*}{$\begin{array}{l}\text { OR } \\
95 \\
\% \\
\text { CI }\end{array}$} & \multicolumn{3}{|c|}{$(95 \%) \mathrm{CI}$} \\
\hline & & \multirow{2}{*}{$\begin{array}{l}\text { Pat } \\
\text { uh } \\
\text { f }\end{array}$} & \multicolumn{2}{|c|}{ Tidak patuh } & & & \multirow[t]{2}{*}{ lower } & \multicolumn{2}{|c|}{ upper } \\
\hline & & & $\%$ & $\mathrm{f}$ & & & & & \\
\hline JK & $\begin{array}{l}\mathrm{P} \\
\mathrm{L}\end{array}$ & $\begin{array}{l}17 \\
6\end{array}$ & $\begin{array}{l}39, \\
5 \\
14, \\
0\end{array}$ & $\begin{array}{l}16 \\
4\end{array}$ & $\begin{array}{l}37,2 \\
9,3\end{array}$ & $\begin{array}{l}0,9 \\
13\end{array}$ & $\begin{array}{l}0,70 \\
8\end{array}$ & $\begin{array}{l}0,1 \\
68\end{array}$ & $\begin{array}{l}2, \\
9 \\
8 \\
2\end{array}$ \\
\hline $\mathrm{U}$ & $\begin{array}{l}\text { Tua } \\
\text { Muda }\end{array}$ & $\begin{array}{l}10 \\
13\end{array}$ & $\begin{array}{l}23 \\
3 \\
30 \\
2\end{array}$ & $\begin{array}{l}0 \\
20\end{array}$ & $\begin{array}{l}0,0 \\
46,5\end{array}$ & $\begin{array}{l}0,0 \\
03\end{array}$ & 2,54 & $\begin{array}{l}1,6 \\
63\end{array}$ & $\begin{array}{l}3, \\
8 \\
7 \\
6\end{array}$ \\
\hline & $\begin{array}{l}\text { Baik } \\
\text { Kuran } \\
\text { g baik }\end{array}$ & $\begin{array}{l}21 \\
2\end{array}$ & $\begin{array}{l}48, \\
8 \\
4,7\end{array}$ & $\begin{array}{l}7 \\
13\end{array}$ & $\begin{array}{l}16,3 \\
30,2\end{array}$ & $\begin{array}{l}0,0 \\
00\end{array}$ & $\begin{array}{l}19,5 \\
0\end{array}$ & $\begin{array}{l}3,5 \\
02\end{array}$ & $\begin{array}{l}1 \\
0 \\
8, \\
5 \\
7\end{array}$ \\
\hline $\begin{array}{l}\text { Sik } \\
\text { ap }\end{array}$ & $\begin{array}{l}\text { Positif } \\
\text { Negat } \\
\text { if }\end{array}$ & $\begin{array}{l}23 \\
0\end{array}$ & $\begin{array}{l}53, \\
5 \\
0,0\end{array}$ & $\begin{array}{l}13 \\
7\end{array}$ & $\begin{array}{l}30,2 \\
16,3\end{array}$ & $\begin{array}{l}0,0 \\
07\end{array}$ & $\begin{array}{l}0,36 \\
1\end{array}$ & $\begin{array}{l}0,2 \\
34\end{array}$ & $\begin{array}{l}0, \\
5 \\
5 \\
8\end{array}$ \\
\hline $\begin{array}{l}\mathrm{m} . \mathrm{k} \\
\text { erja }\end{array}$ & $\begin{array}{l}\text { Lama } \\
\text { Baru }\end{array}$ & $\begin{array}{l}18 \\
5\end{array}$ & $\begin{array}{l}41, \\
9 \\
11, \\
6\end{array}$ & $\begin{array}{l}3 \\
7\end{array}$ & $\begin{array}{l}7,0 \\
39,5\end{array}$ & $\begin{array}{l}0,0 \\
00\end{array}$ & $\begin{array}{l}20,4 \\
0\end{array}$ & $\begin{array}{l}4,2 \\
13\end{array}$ & $\begin{array}{l}9 \\
8, \\
7 \\
8 \\
3\end{array}$ \\
\hline
\end{tabular}

Primer Data 2017

\section{DISCUSSION}

Relationship between Gender and Nurse Compliance in implementing the standard catheter installation. Chi Square analysis results obtained $\mathrm{p}$ $=0.913(\mathrm{p}>0.05)$, meaning that the sexes of men and women who have different characters were not proven to be associated with nurses' 
compliance in implementing catheter installation standards in Bantul Hospital. Based on the analysis results obtained an odd ratio value of 0.708 . Odd ratio values of less than 1 indicate that gender is a protective factor for the formation of nurses' adherence to the implementation of the standard catheter installation in Bantul Hospital. This is supported by the opinion of Robbins (2007) which states there are no consistent differences in men and women in terms of problem solving, analytical skills, motivation, sociability and learning ability. This is also supported by Judha (2015) “" There is no difference between men and women but the difference is experience in solving problems".

Relationship between Age and Nurse Compliance in the implementation of the standard catheter installation. Age is the age range that is calculated since the individual was born until now. The results of the cross tabulation are known to the majority of nurses in the old category obedient in carrying out catheter installation according to the standard of $23.3 \%$. While nurses in the young category were mostly not compliant in carrying out catheter fitting according to the standard of $46.5 \%$. Chi Square analysis results obtained $\mathrm{p}=$ 0.003 ( $\mathrm{p}<0.05)$, meaning that there is a significant correlation of age with nurses' compliance in the implementation of the standard urethral catheter installation in Bantul Hospital, so that the hypothesis of this study is accepted. , 54 at $95 \%$ CI between 1,663-3,876, it can be interpreted that nurses who are elderly have the opportunity to comply with the urethral catheter installation standard by 2.54 times compared to younger nurses. This result is supported by Hurlock in Wawan and Dewi (2010) which states that the more age, the level of maturity and strength of a person will be more mature in thinking and working.

Relationship between Knowledge and Compliance of Nurses in the implementation of catheter installation standards. Knowledge is the result obtained by a person after doing damage to certain objects. The results of the analysis revealed that most nurses had good knowledge in the category of $65.1 \%$. The results of cross-tabulation of most nurses who have good category knowledge, obedient in carrying out the installation of catheters according to the standard of $48.8 \%$. While nurses who have poor knowledge are mostly not compliant in carrying out the catheter installation according to the standard of $30.2 \%$, Chi Square analysis results obtained $\mathrm{p}=0,000(\mathrm{p}$ $<0.05$ ), meaning that there is a significant relationship of knowledge with nurse compliance in implementation urethral catheter installation standards in Bantul Hospital, so that the hypothesis of this study is accepted Based on the results of the analysis obtained an odd ratio value 
of 19.50 at $95 \%$ CI between $3.502-108.57$ can be interpreted that nurses who have good knowledge have the opportunity to obey implement the standard urethral catheter installation of 19,50 times compared to the poor knowledge, this is in accordance with the theory put forward by Notoatmodjo (2007) which states that knowledge is a very important domain in the formation of a person's behavior.

Relationship between Attitude and Compliance with the implementation of the catheter installation standards. Attitude is a closed response from the stimulus. The results of the analysis revealed that most nurses had a positive attitude of $83.7 \%$. Positive results indicate the nurse's support for the implementation of catheter installation in accordance with standards.

A positive attitude is the basis for taking the right action in accordance with a concept that has been believed to be true. a positive attitude will then have a tendency to take the right and obedient actions in the standard implementation of urethral catheters. The analysis showed that the majority of nurses who had a positive attitude were $53.3 \%$. While nurses who had a negative attitude were 16.3\%. Chi Square analysis results obtained $\mathrm{p}=$ $0.007(\mathrm{p}<0.05)$, meaning that there is a significant relationship between attitude and nurse compliance in the implementation of the standard urethral catheter installation in Bantul Hospital. Based on the analysis results obtained an odd ratio value of 0.361 . Odd ratio value of less than 1 indicates that attitude is a protective factor in the formation of adherence to the implementation of the standard urethral catheter installation in Bantul Hospital. According to the theory of Thomas and Znaniec in Azwar (2006) which states that attitude is a predisposition to perform certain actions or behaviors.

Relationship of Work Period with Nurse Compliance in the Implementation of Standard Catheter Installation. The work period is the amount of time someone has traveled in carrying out a particular profession. The results of the analysis revealed that most nurses had a new working period ( $<5$ years) of $51.2 \%$. These results indicate that the length of service of nurses is still relatively short, the results of the study showed that most nurses who had a long service life (> 5 years) amounted to $41.9 \%$. While nurses who have a new working period ( $<5$ years) $39.5 \%$. Chi Square analysis results obtained $\mathrm{p}=0,000(\mathrm{p}$ $<0.05$ ), meaning that there is a significant relationship of work period with nurse compliance in the implementation of the standard installation of urethral catheters in Bantul Hospital. Based on the analysis results obtained an odd ratio value of 20.40 at $95 \%$ CI between 4,213-98.79 can be interpreted that nurses who have a long service life (> 5 years) have the opportunity to obey the 
standard installation of urethral catheters of 20.40 times compared to nurses with tenure new $(<5$ years). In accordance with Robbins (2007) which states that there is a positive relationship between seniority and work productivity. According to the theory put forward by Hartono et al in Sugiartono (2007) which states that the longer the service period of an officer the more his skills will be in obeying regulations.

\section{CONCLUSION}

There is a significant relationship between age, knowledge, attitude, and length of service of nurses' compliance in implementing the standard urethral catheter installation in Bantul Hospital.

\section{SUGGESTION.}

It is expected that efforts are needed to improve nurses' compliance in the implementation of urethral catheter installation standards through the provision of education and training with knowledge about the standards for urethral catheter installation and the importance of complying with procedures in accordance with those established in hospitals for the safety of patients and officers as well as conducting improvements to the surveillance system with pay attention to the procedure for implementing urethral catheters.

\section{REFERENCES}

Anonim. 2010. Google.com. http://standardoperating-procedure.com/. Diakses Tanggal 15 desember 2010. Pukul 19.00 WIB

Alimudin, 2008. Sistem Penilaian Hasil Belajar. Http//:penilaianhasilbelajar.blogspot.com.

Diakses Tanggal 21 Januari 2011. Pukul 20.00 WIB.

Alimul Aziz, 2004. Buku Saku Praktikum Kebutuhan Dasar Manusia. Jakarta. EGC

Ardianto , 2008. Faktor-Faktor Yang Berhubungan Dengan Kepatuhan Perawat Dalam Pemasangan Infuse Intravena Di Instalasi Gawat Darurat Rsud Indrasari Regat. Skripsi. Program Studi Ilmu Keperawatan Fakultas Kedokteran Universitas Gadjah Mada.

Azwar,A., 1996, Program Menjaga Mutu Pelayanan Kesehatan (Aplikasi Prinsip Lingkaran Pemecah Masalah ). Jakarta. yayasan penerbit ikatan dokter Indonesia, Jakarta.

Azwar, S. 2006. Sikap Manusia Teori dan Pengukurannya. Jakarta : Pustaka Pelajar

--------. 2010. Sikap Manusia Teori dan Pengukurannya edisi 2. Jakarta : Pustaka Pelajar

Depkes RI, 1993. Instrument Evaluasi Penerapan Asuhan Keperawatan Dirumah Sakit. Cetakan I. Direktorat Rumah Sakit Umum Dan Pendidikan Direktorat Jendral Pelayanan Medik Departemen Kesehatan Medik.

Ely, A. 2000. Faktor-faktor Yang Berhubungan Dengan Kepatuhan Perawat Menerapkan 
Standar Asuhan Keperawatan Pada

Puskesmas Rawat Inap Di Kabupaten Sleman. Program Pasca Sarjana, Universitas Gadja Mada, Yogyakarta . Research Report From JKPKBPPK/2004-05-2006.

http://digilib.litbang.depkes.go.id. Diakses 20 Juni 2016.

Gibson ; James.,2000. Organisasi: perilaku, stuktur, proses. Jakarta . Erlangga.

Handayani, T., 2005. Faktor-Faktor Yang Mempengaruhi Kepatuhan Perawat Dalam Pelaksanaan Protap Pemasangan Dan Dressing Kateter Uretra Di Bangsal Rawat Inap RSUP Dr Soeradji Tirtonegoro Klaten. Skripsi. Program Studi Ilmu Keperawatan Fakultas Kedokteran Universitas Gadjah Mada.

Heather, M. dan Hannie, G. 2001. Penjaminan Kualitas Dalam Keperawatan : Konsep, Metode dan Studi Kasus. Cetakan I. Alih Bahasa : James Veldman. Jakarta. EGC.

Judha, Mohamad dan Deden Iwan. S, 2015. Apa dan bagaimana Penyakit Lupus?. Yogakarta, Nuha Medika

Kasmad, 2007. Hubungan Antara Kualitas Perawatan Kateter Dengan Kejadian Infeksi Nosokomial Saluran Kemih. http://ejournal.undip.ac.id/index.php/mediane rs/article/download/237/141 diakses tanggal 08/ 02-2011. pukul 09.00 WIB.

Listiana et all, 2009. Panduan Praktikum Kebutuhan Dasar Manusia. Program Studi Ilmu Keperawatan Fakultas Ilmu Kesehatan Universitas Respati Yogyakarta.

Masong. 1982. Assertion And Defence Mechanism Preference. Journal of Counseling Psychology.vol 6, American Phychology Association inc.
Murrti, B, 1997. Penerapan Metode Statistic NonParametrik Dalam Ilmu-Ilmu Kesehatan. Jakarta : Gramedia

Nursalam, 2002. Menejemen Keperawatan Amplikasi Dalam Praktek Keperwatan Professional . Jakarta. Salemba medika.

-------,2003. Konsep Dan Penerapan Metodologi Penelitian Ilmu Kepearawatan: Edisi Petama. Jakarta. Salemba Medika.

----------,2009. Konsep Dan Penerapan Metodologi Penelitian Ilmu Kepearawatan: Edisi kedua. Jakarta. Salemba Medika.

Notoatmodjo, 2002. Metodologi penelitian kesehatan. Jakarta. PT Rineka Cipta.

---------, 2007. kesehatan masyarakat ilmu dan seni. Jakarta. PT Rineka Cipta.

Panggabean, R. 2007. Hubungan Pengetahuan Dan Sikap Petugas Laboratorium Terhadap Kepatuhan Dalam Menerapkan Standar Operasional Prosedur (STANDART) Di Puskesma Kota Pekan Baru. Tesis. Program Pasca Sarjana Universitas Sumatera utara Fakultas Ilmu kesehatan masyarakat..

Perawat Bloger, 2006. Pedoman Pengembangan Jenjang Karir Profesi Keperawatan Direktorat Bina Pelayanan Keperawatan . www.asuhankeperawatan.com. diakses tanggal 20 januari.2010. pukul 21.00 WIB.

Potter, P.A.,Perry, A.G.,2005. Buku Ajar Fundamental Keperawatan: Konsep, Proses, Dan Praktik Volume I. Edisi 4. Jakarta. EGC.

-------, P.A.,Perry, A.G.,2005. Buku Ajar Fundamental Keperawatan: Konsep, Proses, Dan Praktik Volume II. Edisi 4. Jakarta. EGC.

PPNI,1999, Standar Praktek Keperawatan Professional (Perawat Terrgristasi,DPP PPNi). Jakarta.

Ribek , 2000. Analisis Lama Waktu Tindakan Keperawatan Pemasangan Kateter dan Infus 
Diruang Penyakit Dalam, Rumah Sakit Umum Pusat Dr. Sarjito, Yogyakarta Skripsi. Program Studi Ilmu Keperawatan Fakultas Kedokteran Universitas Gadjah Mada.

Riyadi, S,. 2007. Faktor Internal Dan Eksternal Yang Berhubungan Dengan Kepatuhan Operator Dalam Mengikuti Prosedur OperasiDi

Industri.http://www.binakesehatankerja.com. diakses Tanggal 16 Desember 2010. Pukul 20 WIB .

Robbins, S.p., 2007 Perilaku Organisasi Edisi Lengkap. Jakarta. Mancan Jaya Cermerlang .

RSUD Panembahan Senopati Bantul, 2010. Laporan infeksi saluran kemih

Sabri, Luknis, 2006. Statitis Kesehatan.Jakarta. PT Raja Grafindo Persada.

Setya, Kristina (2007). Analisi Faktor-Faktor Yang Mempengaruhi Kepatuhan Perawat Dalam Pendokumentasian Asuhan Keperawatan. $\quad$ http//.find-docs./teorikepatuhan-doc.html.diakses pada tanggal 20 januari 2011. Pukul 21.00 WIB.

Sugiartono, 2007. Faktor-faktor Yang Berhubungan Dengan Kepatuhan Petugas P2TBC Puskesma Terhadap Tatalaksana Standar Pelayanan Tuberkolosis Strategi DOTS Di Kabupaten Bandung Provinsi Jawa Barat. Skripsi. Program studi ilmu kesehatan masyarakat fakultas kedokteran. Univesitas

Suharsimi, A. 2006. Prosedur Penelitian: Suatu Pendekatan Praktek. Edisi Revisi VI. Jakarta. Rineka Cipta.

Tim penyusun Kamus Pusat Bahasa, 2007. Kamus besar bahasa Indonesia edisi 3 Cetakan 4, Jakarta. Balai Pustaka

Sugiono, 2008. Metodologi Penelitian Kuantitatif $R \& D$. bandung. Alfabeta

Tietjen, L,.et all, 2005. Panduan Pencegahan Infeksi Untuk Fasilitas Pelayanan Kesehatan
Dengan Sumber Daya Terbatas. Jakarta. Yayasan Bina Pustaka Sarwono Prawirohardjo.

Undang-Undang Republik Indonesia Nomor 36 Tahun 2009 Tentang Kesehatan http://www.pppl.depkes.go.id/_asset/_regulas i/UU_36_Tahun_2009\%5B1\%5D.pdf.

Diakses tanggal 08-02-2011.pukul 09.00WIB.

Wahyudi, 1996. Manajemen Sumber Daya Manusi, Bandung sulita.

Wawan Dan Dewi, 2010. Teori Dan Pengukuran Pengetahuan,Sikap, Dan Prilaku Manusia. Nuha medika. Jakarata.

Widiyanti. R.S., 2007. Pengaruh Sosialisasi Prosedur Tetap Pemasangan Infus Terhadap Tingkat Kepatuhan Perawat Di Rumah Sakit TK.II Dr. Soedjono Magelang.Proposal.Program Studi Ilmu Keperawatan Stikes Surya Global 